\title{
BUSINESS ENVIRONMENT AND THE INCORPORATION DECISION
}

\author{
Asli Demirguc-Kunt Inessa Love Vojislav Maksimovic*
}

\begin{abstract}
Using firm-level data from 52 countries, we investigate how a country's institutions and business environment affect firms' organizational choices and the effects of the organizational form on access to finance and growth. We find that businesses are more likely to choose the corporate form in countries with developed financial sectors and efficient legal systems, strong shareholder and creditor rights, low regulatory burdens and corporate taxes and efficient bankruptcy processes. Corporations report fewer financing, legal and regulatory obstacles than unincorporated firms and this advantage is greater in countries with more developed institutions and favorable business environments. We find some evidence of higher growth of incorporated businesses in countries with good financial and legal institutions.
\end{abstract}

World Bank Policy Research Working Paper 3317, May 2004

The Policy Research Working Paper Series disseminates the findings of work in progress to encourage the exchange of ideas about development issues. An objective of the series is to get the findings out quickly, even if the presentations are less than fully polished. The papers carry the names of the authors and should be cited accordingly. The findings, interpretations, and conclusions expressed in this paper are entirely those of the authors. They do not necessarily represent the view of the World Bank, its Executive Directors, or the countries they represent. Policy Research Working Papers are available online at http:/lecon.worldbank.org.

* Demirguc-Kunt and Love are respectively Research Manager, Finance Team, Development Research Group, World Bank, and Financial Economist, Finance Team, Development Research Group, World Bank. Maksimovic is the Bank of America Professor of Finance, Robert H. Smith School of Business at the University of Maryland. 


\section{Introduction}

The role that institutions play in the governance of businesses has received a great deal of attention recently. We know from the economics and business history literature that during the industrial revolution economic development was associated with the rise of the limited liability corporation. In the United Kingdom, for example, there was a general perception in the early years of the $19^{\text {th }}$ century that the prevailing partnership structure was inadequate to support the transactions required by a modern business. In particular, unlike corporations, then prevalent partnerships did not have a separate legal identity from their owners. This fact made even simple legal transactions, such as suing to recover damages, complex. As was noted at the time, the concomitant unlimited liability made it more difficult to obtain investment funds, especially from wealthy investors. ${ }^{1}$ As a result, in the United Kingdom and other leading industrial countries, there were repeated attempts to provide a better legal framework for the organization of business enterprise. In response, laws that authorized the formation of limited liability corporations were passed in the second half of the nineteenth century.

Contemporary finance research suggests that these historical concerns about organizational form were well founded. We now know that a country's legal system and corporate ownership affect the financing of firms (La Porta, Lopez-de-Silanes, Shleifer and Vishny $(1998,2000)$ and La Porta, Lopez-de-Silanes, Shleifer $(2002,2003))$. On theoretical grounds we expect unincorporated businesses to suffer from difficulties in raising capital (Winton (1995)). Empirically, in a study of 11,000 German businesses, Harhoff, Stahl, and Woywode (1998), find that incorporated firms grow faster than unincorporated firms. $^{2}$

\footnotetext{
${ }^{1}$ See Anderson and Tollison (1983), Dubois (1971) and especially Shannon (1931, 1934).

${ }^{2}$ Using Mexican data, Laeven and Woodruff (2003) argue that owners of unincorporated firms are exposed to significantly greater idiosyncratic risk in localities with poor legal enforcement and that, as a result, unincorporated firms are relatively small in such localities.
} 
While historically the use of the corporate form is associated with economic development, the advantage of the corporate form over other forms of legal organization, such as partnerships or sole proprietorships, rests on institutional factors that differ across countries. There are significant differences in legal and financial systems around the world. In some countries corporate taxes are higher than personal income taxes paid by proprietors of unincorporated businesses and in others they are lower. The level of business regulation also differs markedly across countries. As a result, we expect that the prevalence of limited liability organizational forms also differs across countries.

In this paper we ask how institutions and business environment affect firms' organizational choices and what are the effects of this organizational form on firms' access to finance and growth. More specifically, the questions we ask are:

- Does the quality of the legal and financial systems in a country predict whether businesses choose to incorporate? What role does the efficiency of the bankruptcy process play? Do bureaucratic obstacles to incorporation significantly inhibit the process of corporation formation in some countries?

- Do unincorporated businesses face greater obstacles than corporations? Specifically, do they report greater financial, legal and regulatory obstacles in the operation and growth of their businesses? Does a country's level of development affect the relative gains from incorporating a business?

- Is there evidence that limited liability corporations grow faster than unincorporated businesses? If so, does the difference in growth rates depend on the quality of institutions in the country?

In addressing these questions, we use firm-level data for 52 countries from the World Business Environment Survey (WBES), a cross-sectional, firm-level survey that includes the assessment of 
financial, legal and other obstacles to growth as reported by incorporated and unincorporated businesses. The detailed information provided about the businesses and the inclusion of small and medium-size businesses make this database unique.

We examine the role of limited liability in the choice of corporate form. We find that businesses are more likely to become corporations in countries with more developed financial and legal systems and strong creditor and shareholder rights. We also find that firms are more likely to operate as unincorporated businesses in countries with weak and ineffectual bankruptcy processes. At all levels of development, businesses are more likely to operate as corporations in countries where the tax disadvantages of doing so are smaller and where the regulatory burdens in obtaining corporate status are lower.

Our results indicate that in countries with more developed institutions, incorporated businesses report lower obstacles to operations and growth than unincorporated businesses. Specifically, corporations report lower financial obstacles than unincorporated businesses in countries with more developed financial systems. Corporations also report lower legal obstacles than unincorporated businesses in countries with a tradition for using the legal system to arbitrate disputes. They report relatively fewer problems with corruption than unincorporated businesses in countries where corruption is less common.

Incorporated businesses do not on average grow faster than unincorporated businesses. However, we find evidence that incorporated businesses on average grow faster than unincorporated businesses in countries with high-quality legal systems and institutions that support formal contracting - more developed financial system, less corruption, more efficient bankruptcy processes and shorter processes for registering businesses. ${ }^{3}$ Taken together, our results support the view that

\footnotetext{
${ }^{3}$ Thus, our results are consistent with Harhoff, Stahl, and Woywode (1998) study of the growth of firms in Germany, a developed country, but do not support a generalization of their findings to underdeveloped countries.
} 
corporations are better adapted than unincorporated businesses for facilitating access to financial markets and for formal contracting with customers and investors. Such transactions are important in developed economies with efficient legal systems but less so in developing countries. Unincorporated businesses have a comparative advantage in operating in informal environments where businesses are self-financing and rely on their reputations rather than on legally enforceable contractual obligations.

Our approach complements the existing finance literature on organizational form. The early literature was theoretical and focused on the role of limited liability and taxes in the selection of organizational form. Winton (1995), Easterbrook and Fischel (1985) and John and Senbet (1996) focus on the advantages of limited liability that accrue from the fact that owners are protected from claims by third parties for any damages that the limited liability firm causes. ${ }^{4}$ An exception is the work of Gordon and McKie-Mason $(1994,1997)$ and Goolsbee (1998), who estimate the cost of the excess tax burden paid by incorporated small businesses in the United States. Gordon and McKie-Mason (1997) argue that the average incorporated business must obtain an additional benefit equal to approximately 7 percent of its earnings each year from the incorporated state in order to compensate it for the excess tax burden.

More recently, two contributions have argued that, at least in businesses that do not rely on external financing, partnerships have advantages over corporations. Levin and Tadelis (2002) argue that partnerships have an incentive to underproduce because their incentive structures prevent them from correctly pricing the marginal unit of labor they employ. They show that for some businesses this inefficiency can create value because it allows partnerships to commit credibly not to expand output at the cost of lowering quality. Thus, partnerships find it easier to acquire a reputation for quality. Such reputations are especially valuable in environments where performance cannot be contractually

\footnotetext{
${ }^{4}$ They are also protected against claims from customers and investors. However, the value of this protection is incorporated in market prices at which the firm transacts.
} 
ensured. By contrast, Morrison and Wilhelm (2003) argue that partnerships can create value precisely because they permit the setting of complex incentives that are not publicly revealed.

The rest of the paper is organized as follows. We discuss our conceptual framework in section II. The data are discussed in section III. The results are presented in section IV. Section V concludes. The data sources and detailed variable definitions are given in the Data Appendix.

\section{Motivation}

Easterbrook and Fischel (1985) argue that most of the advantages of the corporate form, such as limited liability, can in principle be obtained by private contracting between business proprietors or partners and their creditors and customers. This view holds that corporate form is largely irrelevant. Thus, corporations and unincorporated businesses should be able to finance their activities similarly. Abstracting from taxes, incorporated and unincorporated businesses would differ only in the legal and regulatory fees that they may incur in obtaining the requisite legal characteristics. ${ }^{5}$

While the Easterbrook and Fischel (1985) view is valid in a world without transactions costs, the extent to which it is valid in a world with transactions costs and in countries with inefficient legal systems is an open question. In the limit, if property rights are sufficiently poorly defined, the legal form of a business is irrelevant. However, when the legal system is somewhat effective but recontracting around the corporate form is costly, then the choice of institutional form may be important. Accordingly, businesses are likely to adapt to their country's institutions by choosing legal forms that allow them to enter into optimal contracts with customers and investors while economizing on exposure to institutional and regulatory costs. We refer to this view as the "adaptive" view and

\footnotetext{
${ }^{5}$ Ass pointed out by Anderson and Tollison (1983) and Dubois (1971), before the coming of limited liability some partnerships tried to approximate some features of the joint stock companies by forming trusts which were charged with operating the partnerships on behalf of the partners.
} 
examine the institutional factors that affect firms' choice of legal form as the institutional environment changes.

Corporations and unincorporated businesses differ in several important respects. First, unlike a sole proprietorship or a partnership, a corporation has an independent legal identity, usually with a continuity of life. Management is centralized and can act on behalf of the owners. These factors permit the corporation to take advantage of more efficient contracting than is possible for a non-incorporated business with multiple owners. Second, the owners of a corporation are entitled to limited liability. Third, the fact that a corporation has an identity separate from its owners also usually implies that there is freer transferability of ownership stakes. Fourth, in many countries a corporation faces a different tax schedule and a different regulatory environment than an unincorporated firm. We discuss each of these factors below.

\section{Efficient Contracting}

Shannon (1934), in particular, notes that there exist significant transactions costs because the partnership in its pure form (or sole proprietorship) is not a separate entity from its owners. He argues that these costs were a major cost of this organizational form in the nineteenth century. Thus, for example, a partnership undergoes a change when a principal partner leaves or a new partner is added. These changes may affect the status of existing legal contracts and claims by and against the partnership. ${ }^{6}$ In the same vein, in common law, legal disputes within partnerships carry a risk that the court will dissolve the partnership in settling a case between partners. This risk means that the incentives for a partner to sue other partners are very different from those of a shareholder suing the managers of a firm. Taken together, these costs suggest that a corporation is better adapted to the

\footnotetext{
${ }^{6}$ Under common law, if a customer sued a partnership for non-delivery he might have had to initiate separate legal actions for each change in the composition of the partnership during the period of the dispute. Similarly, a partnership that sues a customer would have to do the same. A case in which an individual is a partner in both the plaintiff and defendant partnerships might not have been allowed to proceed (Shannon (1934)). A single partner could derail a legal case against his partnership by simply physically moving outside the jurisdiction of the British legal system.
} 
complex transactions of a developed economy where disputes are mediated by the courts. Thus, a partnership or sole proprietorship may have a comparative advantage in an economy where firms rely on implicit contracts and the principal punishment for transgressions is the loss of a firm's reputation. ${ }^{7}$

\section{Limited Liability}

Business historians attach great importance to the development of the limited liability corporation. Intuitively, unlimited liability increases the risk borne by the owners of an unincorporated business. As a result of this increased risk, the owners will be unwilling to borrow enough to fund investment opportunities that would have been profitable in the absence of unlimited liability. However, the fact that the owners' property is not protected from business creditors also increases their incentives to honor contracts with creditors. Thus, from the perspective of the financial institutions, limited liability makes lending to an incorporated business riskier, reducing their willingness to lend.

\section{Sales of ownership stakes}

Unlimited liability might affect firms' ability to raise new capital. Winton (1995) argues that unlimited liability reduces a business's pool of investors by making the value of the firm depend on the changing identities of its owners. This dependence discourages relatively rich investors. When valuing an investment opportunity in an unlimited liability business, a potential investor must not only value the potential of the business, but also evaluate his exposure to any losses the business may incur. This exposure depends on the wealth of the other investors in the business. The exposure is greater the greater the wealth of the investor relative to other investors. The relation between investors' wealth and exposure creates an adverse selection problem that makes it costly for an unlimited liability business to attract wealthy, and therefore less risk-averse investors. By incorporating as a limited liability corporation, the business can avoid this adverse selection problem.

\footnotetext{
${ }^{7}$ See Gomes (2000) for a discussion of financial contracting in economies with ineffective legal systems.
} 
Carr and Mathewson (1988) argue in a similar vein that unlimited liability banks in Scotland in the $19^{\text {th }}$ century suffered from the inability to attract capital and thereby compete effectively with several banks that had limited liability by Royal Charter. This handicap was not corrected until banking regulations were changed to permit the banks to switch to limited liability status. Carr and Mathewson go beyond the economic data to also argue that the banks with limited liability used political means to prevent other banks from obtaining limited liability and becoming stronger competitors. In our context, their analysis raises the possibility that the proportion of businesses in a country adopting a corporate form may directly affect the potential for competition.

\section{Regulatory Environment}

Finally, by incorporating, firms face a different regulatory environment compared to unincorporated firms. Corporations in many countries pay higher taxes since they pay a corporate income tax in addition to the income and dividend taxes paid by investors. Being incorporated may also subject the firm to additional government regulations such as customs and trade regulations, labor and safety regulations. Incorporated firms may also be subject to greater amount of bureaucratic hassle and corruption. The choice of organizational form would be determined by these potential costs of incorporation in addition to the benefits discussed above.

\section{Institutional Differences and Firm's Choices of Legal Form}

The adaptive view suggests that in countries with well functioning legal systems, the corporate firms are better adapted than unincorporated firms for obtaining access to financial markets and for efficient contracting with customers and investors. ${ }^{8}$ By contrast, an unincorporated firm is likely to be more adapted to operating in informal business environments where businesses rely on their reputations rather than on legally enforceable contractual obligations. In such contexts the

\footnotetext{
${ }^{8}$ This does not rule out the possibility that for a subset of businesses, especially service firms, partnerships may be superior, perhaps for the reasons identified by Levin and Tadelis (2002) or Morrison and Wilhelm (2003).
} 
unincorporated form ensures that the owners of a business bear the full cost of a loss of reputation, and thereby provides them stronger incentives to abide by implicit agreements. ${ }^{9}$

The adaptive view predicts that firms are more likely to choose the corporate form in countries with developed financial and legal systems. Thus, according to this view corporations are more prevalent in countries where the legal system is efficient, where creditor and shareholder rights are strong, and where regulatory burdens of conducting business in the formal sector are smaller.

The adaptive view also holds that effective bankruptcy laws, which allow creditors to take over and redeploy the assets of an insolvent business, have two effects on the incentives of firms to adopt the corporate form. First, effective bankruptcy laws reduce the risks of external financing for creditors, thereby making higher leverage feasible. Second, effective bankruptcy procedures increase the costs of unlimited liability to the owners of unincorporated businesses. It also creates an incentive for the owners to diversify away from the business, which is more easily done by the owners of a corporation, leading to a positive relation between the efficiency of the bankruptcy process and rate of incorporation. Such a relation is consistent with Winton's (1995) model of adverse selection under unlimited liability in the market for ownerships stakes in businesses. In our context, we would expect this adverse selection to be more significant in countries where the creditors of a failed business can use the legal system to quickly and efficiently recover from the owners.

The adaptive view also predicts that unincorporated firms are more common in countries where the tax system imposes a heavier tax burden on incorporated firms. This effect is likely to be especially strong in countries with tax systems that are inefficient and open to corruption. This is because the additional tax filings entailed by corporate status are likely to bring an additional level of scrutiny by the authorities and make it more difficult (or more expensive) to avoid taxes.

\footnotetext{
${ }^{9}$ There is an interesting parallel with the venture capitalist industry in the US. Venture capitalists often require entrepreneurs to personally guarantee loans to their businesses, even when these businesses are nominally organized as limited liability firms and when the value of the investments greatly exceed the wealth of the entrepreneurs.
} 
The adaptive view suggests that businesses in a country incorporate until the benefit of incorporation for the marginal firm equals its costs. In countries with developed financial and legal systems this equality is attained when a larger proportion of firms has incorporated. However, even in such countries there may still be businesses for which the tax and cost advantages of remaining unincorporated outweighs the contractual advantages. This is consistent with the models of Maksimovic and Zechner (1991) and Hermalin (1994), who argue that there exists an equilibrium degree of organizational and financing heterogeneity among firms and that the organizational form better adapted to the market environment is observed more frequently. ${ }^{10}$

We test the following predictions of the adaptive view. We first estimate the probability that a business is incorporated, as a function of the institutional and business environment and firm characteristics. We test whether there exist relations between specific institutional features and the choice to incorporate consistent with the predictions of the adaptive view.

Second, we test how corporations and unincorporated firms are affected by important features of the business environment that constrain the operation and growth of their businesses. Specifically, we investigate obstacles in obtaining financing, in dealing with the legal system, the corruption of government officials and taxes and regulations. To do this, we correlate the reports of businesses describing the obstacles they face with their organizational forms and other business-level and country-level variables. We investigate whether incorporated firms have a comparative advantage over unincorporated firms when they operate in countries with better legal and financial systems as the adaptive view predicts.

\footnotetext{
${ }^{10}$ The argument that the proportions of different types of firms adjust in equilibrium is akin to Miller's (1977) argument that firms' capital structures adjust until the tax-advantages of debt and equity are equalized. The assumption of equilibrium is appropriate in this context because it is feasible for businesses to change their status by registering as corporations.
} 
Third, we test whether the growth rates of unincorporated businesses and corporations differ across financial and legal systems. In common with the literature, we take firm growth as a proxy for profitability. ${ }^{11}$ We expect that growth rates of firms adopting the organizational form best adapted to their country's institutions, after controlling for firm characteristics, should be higher than those of firms not adopting the best adapted organizational form. Thus, we expect that incorporated firms to grow comparatively faster in countries with better functioning legal and financial systems.

\section{Data}

Our firm-level data are taken from the World Business Environment Survey (WBES) conducted under the leadership of the World Bank in 1999. This is a size-stratified random survey covering more than 4,000 firms in 52 countries. ${ }^{12}$ The main purpose of the survey was to determine how obstacles to firm operation and growth differ across countries and how these obstacles affect firms of different sizes. Unlike the commercially available firm databases covering multiple countries, this survey is unique in its coverage of small and medium enterprises. It groups firms into three categories. It defines small firms as those with five to 50 employees. Medium firms are those that employ 51 to 500 employees, and large firms are those that employ more than 500 employees. Forty percent of the observations are from small firms, another 40 percent are from medium firms, and the remaining 20 percent are from large firms. The survey also reports whether the reporting firm is an unincorporated business (a sole proprietorship or a partnership) or a corporation.

The firms in the sample were asked numerous questions on the financing and legal obstacles they face. They were also asked to report sales, industry, growth, age, whether the firm is an exporter, and numerous detailed questions about their operations.

\footnotetext{
${ }^{11}$ Growth is frequently used as a proxy for performance in cross-country studies. Thus, growth is used as a proxy for performance at the country level by King and Levine (1993), at the industry level by Rajan and Zingales (1998), and at the firm level by Maksimovic and Demirguc-Kunt (1998) and Beck, Maksimovic and Demirguc-Kunt (2004).

${ }^{12}$ The WBES covers 80 economies. However the sample is reduced because most firm-level or country-level variables are missing for 28 countries.
} 
In Table I, Panel A we summarize relevant facts about GDP per capita, institutional development and the proportion of the sampled firms in each country that are corporations. Where possible, country-level variables are 1995-1999 averages. Detailed variable definitions and sources are provided in Appendix Table A1. Table A2 in the Appendix reports the number of firms for each country in the sample.

\section{Insert Table I here}

The countries in the sample show considerable variation in per capita income. They range from Haiti, with an average GDP per capita of $\$ 369$ to United States and Germany, with a per capita income of around $\$ 30,000$. We also report the proportion of corporations in our sample in each country. The proportion of businesses in our sample that are incorporated shows a wide dispersion across countries.

Table I also shows several descriptors of the institutions and business environment. Law and Order is an indicator of the extent of legal development that reflects the degree to which the citizens of a country are willing to accept the established institutions to make and implement laws and adjudicate disputes. It is produced by the International Country Risk rating agency and is scored between 1 and 6 with higher values indicating a strong court system. Financial development is given by sum of two measures. These measures are the ratio of domestic credit to the private sector to GDP and the ratio of stock market capitalization to GDP. These variables are defined and discussed in Beck, Demirguc-Kunt and Levine (2000).

Creditor and Shareholders Rights variables are drawn from La Porta, Lopez-de-Silanes, Shleifer and Vishny (LLSV, 1998) and are general indicators of investors' protections. We also use indicators identifying the legal origin of the country in our empirical analysis, obtained from LLSV (1998). 
We also report several variables that directly measure the cost and benefits of incorporating a business. The variable Duration of Entry is an estimate, in business days, of the time it takes to obtain legal status to operate a firm with limited liability involved in industrial or commercial activity. The expected duration of meeting entry regulations is lowest in Canada (2 days) and is highest in Indonesia (over 6 months). For comparison, in the US it takes 4 days for firms to obtain legal status. This data is obtained from Djankov, La Porta, Lopez-de-Silanes and Shleifer (DLLS, 2002).

In many countries corporations are tax-disadvantaged in that the corporation pays a corporate income tax on its profit which is in addition to any income or dividend taxes paid by investors. We collect and calculate the difference between the taxes paid by investors in corporations and investors in unincorporated enterprises and report them as the variable Tax Disadvantage. Again, there is a wide variation across countries. Incorporated investors are penalized most heavily in Sweden and have the highest comparative advantage in Uruguay. ${ }^{13}$

Table I also reports two descriptors of each country's bankruptcy process. The variable Absolute Priority measures whether the country's law mandates that secured creditors of a bankrupt enterprise are to be paid before other claimants. ${ }^{14}$ This measure is scaled between zero and 1 so that higher values imply stricter observance of priority. A high score on Absolute Priority means that secured creditors are paid before court costs, labour claims and tax claims. A zero on Absolute Priority means that court costs, labour claims, and tax claims have higher priority than secured creditors.

The variable Time in Bankruptcy is an estimate of the actual time, in years, of the potential duration of contested commercial insolvency proceedings for a sample of countries. The duration of

\footnotetext{
${ }^{13}$ Our measure provides a summary of the relative treatment of personal income and corporate taxes. It differs from the measures used by Gordon and McKie-Mason $(1995,1997)$ for the US which take into account the double taxation of corporate dividends. Our measure is consistent with theirs under the assumption that corporate owners employ tax avoidance strategies that eliminate taxes on dividends.

${ }^{14}$ The legal provisions are the threat point in any negotiations between creditors and debtors. In any specific bankruptcy proceedings there may be departures from absolute priority as a result of negotiations. See Senbet and Seward (1995) for a review of the US evidence on departures from absolute priority.
} 
the insolvency procedures was estimated by local insolvency lawyers and measures the expected length of a contested bankruptcy. In our sample the country with the fastest process is Canada (at just under one year) and the country with the longest process is the Brazil (at about ten years). Both Absolute Priority and Time in Bankruptcy are obtained from World Bank (2003).

Finally, we also report actual use of bankruptcy procedures in these countries. Percent of Bankruptcies is given by the ratio of number of bankruptcies to total number of registered firms. It is obtained from Claessens and Klapper (2003).

In Panel B, Table I we show the summary statistics of the firm-level variables. The WBES survey asked entrepreneurs to rate the extent to which financing, legal, corruption, and taxation and regulation problems presented obstacles to the operation and growth of their businesses. A rating of one denotes no obstacle; two, a minor obstacle; three, a moderate obstacle; and four, a major obstacle. These ratings provide a summary measure of the extent to which the financial and the legal systems, corruption, taxation and regulation create obstacles to growth.

The WBES firm-level survey data is based on un-audited self-reports by firms. This contrasts with accounting data where the auditing process provides a measure of quality control. However, the quality of the audit may vary systematically across countries and firm size. ${ }^{15}$ Moreover, financial statements are used by investors and creditors, the stated purpose of the WBES survey is to evaluate the business environment, not firm performance. As a result, the incentives to distort data are likely to be much higher for financial statements than for survey responses. Also, Beck, Demirguc-Kunt and Maksimovic (2004) show that there exist a positive and economically significant relation between the levels of these obstacles reported by firms and the growth rates of the firms. Their findings suggest that these variables are a good measure of the obstacles facing the reporting firms.

\footnotetext{
${ }^{15}$ See, for example, Ball, Kothari, and Robin (2000) and Hung (2001). Note however, that the empirical findings on the relation between institutional development and firm growth Beck, Demirguc-Kunt and Maksimovic (2004) using WBES data are consistent with Demirguc-Kunt and Maksimovic (1998) using financial statement data.
} 
The sample includes firms from manufacturing, services, construction, agriculture, and other industries. Since the optimal organizational form might differ across industries, we keep track of potential industry effects on the choice of organizational structure by noting whether the business operates in manufacturing or the service industry. We also note whether the firm is an exporting firm or foreign owned, and control for the firm's age.

Panel C shows the simple correlation coefficients between incorporation rate and the countrylevel variables in the study. As expected, there are negative and significant correlations between the rate of incorporation and the costs of incorporation (the cost of becoming incorporated and the tax disadvantage of paying taxes at the corporate rate). There are positive and significant correlations between the effectiveness of a country's bankruptcy system (incidence of bankruptcy, speed of resolution and adherence to absolute priority) and the rate of incorporation. More generally, there is a positive relationship between the proportion of incorporated firms and the quality of a country's legal and financial systems, and, in particular, shareholder rights. By contrast there is a negative relationship between the incorporation rate and creditor rights. We explore these relationships further below.

\section{Results}

In Table II we explore the determinants of an enterprise's decision to incorporate. We start with a set of predetermined control variables and then sequentially introduce each of our explanatory variables into a statistical model that predicts whether individual firms are incorporated or not. This procedure avoids the risk that multicollinearity between the explanatory variables would confound the relation between the dependent variable and each of the explanatory variables.

The dependent variable is an incorporation dummy that equals one if a firm is registered as a corporation and zero otherwise (i.e. if the firm is a partnership or a sole proprietorship). The control variables in each case are dummies for foreign ownership of the enterprise, firm size and age, 
industrial sector (manufacturing or service), and a dummy variable that takes a value of one if the firm is an exporter and zero otherwise. We also include the log of GDP per capita as a control variable that proxies for the wealth level of each economy. ${ }^{16}$ Since the advent of limited liability corporations historically occurred in the most developed countries, we expect GDP per capita to control for omitted variables related to the level of development. All models are estimated using logit probability model with heteroskedasticity robust standard errors.

\section{Insert Table II here}

As Table II shows, there exist consistent and significant relationships between several of the control variables and the rate of incorporation. Foreign owned firms are more likely to be incorporated. ${ }^{17}$ Medium, and in particular, small firms are more likely to be partnerships or sole proprietorships, as are firms in the service sector. In most of the models GDP per capita is positively related to the rate of incorporation.

In column 2 we see that financial development is associated with a higher rate of incorporation. This is expected if the incorporation decision is made to improve the firms' ability to raise new financing, particularly in financially more developed countries. We next test the hypothesis that a high quality legal system that protects investor rights is associated with a higher rate of incorporation. As Table II shows, a strong law and order tradition, and laws that respect shareholder and creditor rights are positively related to the formation of corporation. This is consistent with the notion that a separate legal identity for a business enterprise is more valuable in countries where the formal legal system plays an important role as an efficient arbiter in disputes. ${ }^{18}$ Firms in countries

\footnotetext{
${ }^{16}$ Including growth rate of GDP per capita and inflation as additional controls do not lead to significant changes in our results.

${ }^{17}$ This is consistent with the conjecture that the presence of foreign partners makes it difficult for partnerships to enter into binding contracts and makes the separate legal identity inherent in incorporation more valuable. See Shannon (1932) for a discussion of the historical evidence in $19^{\text {th }}$ century Britain.

${ }^{18}$ Interestingly, GDP per capita retains significance in our model except in the specification in which we introduce law and order tradition as an explanatory variable, where it loses significance.
} 
with a common law origin are more likely to incorporate than firms in countries with a French civil law origin. This suggests that a legal origin may have a significant role in the incorporation choice unrelated to the existence of specific investor rights.

Table II also shows that the incorporation rate is inversely related to the costs of incorporation. In countries where the incorporation process takes longer there are relatively fewer corporations (column 6). In countries where the corporate taxes are high relative to personal income taxes there are also fewer corporations (column 7). ${ }^{19}$ Thus, the demand for incorporation is sensitive to the price of incorporation. $^{20}$

We next examine the relation between the efficiency of the bankruptcy process and the rate of incorporation. Table II shows that there is a positive and significant relation between the likelihood that a firm is incorporated and the incidence of bankruptcy proceedings in its country (column 8). Thus, corporations appear to be greater beneficiaries of the bankruptcy protections than partnerships and sole proprietorships. Columns 9 and 10 of Table II also show that the proportion of corporations is higher in countries where the bankruptcy process allows for faster resolution and adheres to absolute priority. This finding is consistent with Winton's (1995) model of adverse selection under unlimited liability in the market for ownerships stakes in businesses.

The efficiency of the bankruptcy processes may also have a direct effect on investors' willingness to maintain an unlimited liability status. As the bankruptcy process becomes more efficient, and recovery by creditors in the event of business failure becomes more certain, the risk borne by the business owners increases. Incorporating as a limited liability corporation reduces that

\footnotetext{
${ }^{19}$ This finding is consistent with the US evidence (Gordon and McKie-Mason $(1994,1997)$ and Goolsbee (1998)).

${ }^{20} \mathrm{We}$ have also explored if the extent of corruption in the country has an impact on the decision to incorporate. Using a country-wide corruption index which increases with lower levels of corruption, we see that incorporation is more likely with less corruption, and when entered into the regression without GDP per capita, this coefficient is significant at ten percent. However, because corruption and GDP per capita are very highly correlated, entering them together introduces multicollinearity.
} 
risk. Therefore, we would again expect to see a positive relation between the efficiency of the bankruptcy procedures and the existence of limited liability firms. ${ }^{21}$ Thus, in countries where bankruptcy procedures are efficient we would expect to see, and we do find, relatively more limited liability businesses.

Although it is interesting to see which one of the legal, taxation, financial, and bankruptcy effects dominate in determining the incorporation decision, it is difficult to identify their differential impact because of the large number of variables we analyse, the high level correlations between these variables and the limited degrees of freedom at the country level. Nevertheless, when we include different groups of variables, we generally see that law and order, shareholder rights, number of bankruptcies and time in bankruptcy retain their significance even when entered together. Finally, we create a composite indicator of institutional development and business environment, Institutions, which is the first principal component of Law and Order, Financial Development, Corruption, Duration of Entry and Time in Bankruptcy variables. ${ }^{22}$ As reported in the last column of Table II, this variable is also positive and significantly correlated with the rate of incorporation.

We next investigate directly whether the corporate form is associated with a reduction in the financial and other obstacles in operating a business. Our measures of obstacles are taken from the WBES database. In Table III we take as our dependent variables the Financing Obstacle (specifications (1) and (2)), Legal Obstacle (specifications (3) and (4)), Corruption Obstacle (specifications (5) and (6)), and the Taxes and Regulations obstacle (specifications (7) and (8)). Each obstacle is measured on a scale (1) - "no obstacle" to (4) - "major obstacle". Our principal variable of interest is the corporation dummy as defined above. Here our purpose is to see if incorporated firms

\footnotetext{
${ }^{21}$ However, this effect would be negated if creditors require the owners of a limited liability firm to personally guarantee loans.

${ }^{22}$ More specifically, we measure it as the fist principal component factor (with factor loadings) of Law and Order (0.55), Financial Development (0.43), Corruption (0.47), Duration of Entry (-0.44) and Time in Bankruptcy (-0.29).
} 
report significantly different obstacles compared to partnerships or sole proprietorships, controlling for other firm characteristics. In addition, we also augment each specification with an appropriate country-level variable that measures the relevant institutional factor in each country that may create the obstacle. Thus, in specifications (1) and (2) which predict the level of the financing obstacles faced by each firm we include Financial Development. Analogously we include Law and Order in specifications (3) and (4) predicting the Legal Obstacle, and a country-wide index of corruption in specifications (5) and (6) predicting the Corruption obstacle. In specifications (7) and (8), predicting the Tax and Regulation obstacle, we include two country-wide control variables, Tax Diff measuring the tax disadvantage of the corporate form and Duration of Entry measuring the bureaucratic complexity of becoming incorporated. In specifications (2), (4), (6) and (8) these additional control variables are interacted with the corporation dummy. This interactive term is intended to identify whether the impact of the corporate form on the obstacles reported by firms varies with institutional development. Estimates are obtained using ordered probit regressions with heteroskedasticity robust standard errors.

\section{Insert Table III}

Table III shows that the corporations report lower obstacles than partnerships and sole proprietorships. In every case the effect is statistically significant in environments where the effect is likely to be material. Thus, corporations report lower financing obstacles than other businesses in countries with more developed financial systems. They report lower legal obstacles in countries with more established legal traditions for settling disputes. Corporations report relatively fewer problems with corruption in countries with lower levels of corruption. Corporations also report fewer problems with taxation and regulation in countries where there taxation of corporations relative to personal income is less onerous and in countries with less complex regulatory requirements for incorporation. 
This finding is consistent with the notion in Gomes (2000) that firms in countries with undeveloped legal systems rely heavily on reputation to enforce contracts. In such contexts the corporation's defining trait, a legal existence separate from its owners, may not have much value for most businesses.

We next examine the performance of incorporated firms and unincorporated firms in different institutional environments. Following the literature, and in view of data limitations, we compare the growth rates of incorporated and unincorporated businesses. ${ }^{23}$ In Table IV we regress sales growth on the corporation dummy and two descriptors of the institutional environment, Law and Order and the Institutions, discussed above.

\section{Insert Table IV}

In Columns (1) and (3), we first present a basic specification, in which the firm growth rate is regressed on the corporation dummy, a descriptor of the institutional environment (Law and order or Institutions, respectively), and firm-level control variables including size dummies. The coefficient of the corporation dummy in this specification will be significantly different from zero if corporations on average have different growth rates than unincorporated businesses, controlling for the average effect of the institutional environment. In order to determine if the effect of incorporation varies by institutional environment, in additional specifications we interact the descriptors of the institutional environment with the corporation dummy.

The coefficient of the corporation dummy in the first specification in Columns (1) and (3) is not statistically significant, implying that the growth rates of corporations and unincorporated businesses do not differ in general. Thus, the corporate form does not appear be associated with higher firm performance in general. The coefficients of Law and Order and Institutions are positive and

\footnotetext{
${ }^{23}$ Growth rates of firms are used as indicators of performance in firm-level cross-country studies by Demirguc-Kunt and Maksimovic (1998), Beck, Demirguc-Kunt and Maksimovic (2004), and in the industry-level study by Rajan and Zingales (1998).
} 
significant, indicating that, on average, businesses grow faster in countries with good institutions and business environments.

In Columns (2) and (4), we interact the corporation dummy with the Institutions and Law and Order, respectively. Corporations grow relatively faster in a country with good legal system and institutions. This is consistent with our findings in Table III that in countries with good legal systems and institutions, corporations face lower financing and other obstacles to the operation and growth of their businesses. In other words, our results suggest that corporations perform relatively less well than unincorporated businesses in countries with poor legal systems.

\section{Conclusion}

Using firm-level data we examine how institutional differences across a cross-section of firms in developed and developing countries affect the proportion of businesses that incorporate. We argue that corporations and unincorporated businesses differ along several dimensions, such as ease of transactions stemming from differences in legal identity; differences in the liability of the owners that might affect the firms' willingness to borrow to fund capital expenditure or for potential owners to buy a stake in the business; and differences in tax and regulatory environments. As a result, corporations are likely to be better adapted for transactions in developed countries where the formal legal system is used to ensure contract compliance. The advantage of corporations is reduced when firms use loss of reputation to assure that contracts are honored.

Empirically, we find that businesses are more likely to adopt the corporate form in countries with developed financial systems, well-established legal traditions, and efficient procedures for resolving bankruptcy. Businesses are less likely to adopt the corporate form in countries where 
government regulations for starting a limited liability corporation are burdensome and where corporate taxes are high in comparison with personal income taxes.

More generally, we find that in countries with good business environments, corporations report fewer obstacles to doing business than non-corporations. Specifically, in countries with developed financial systems, corporations report fewer financial obstacles than other businesses. In countries with good legal systems, corporations report fewer legal obstacles than non-corporations. In countries with low levels of endemic corruption, corporations report fewer problems with corruption than noncorporations. However, there is very little evidence that corporations report fewer obstacles when the business environment is less benign --- when the financial system is undeveloped, the legal system is not used for settling disputes and corruption is endemic.

Taken together our results show that the corporate form has advantages over other business forms in relaxing financing constraints and reducing legal obstacles. However, these advantages manifest only in countries with better developed financial and legal systems.

Corporations do not in general grow faster than unincorporated businesses. Therefore, we find little support for the notion that unlimited liability in general imposes significant costs on businesses by reducing their growth rates. We do find some evidence of higher growth of incorporated businesses in countries with good financial and legal institutions. 


\section{REFERENCES}

Aghion, Phillipe, Patrick Bolton, and Jean Tirole, 2000, Exit options in corporate finance: liquidity versus incentives," Working Paper, Princeton University, Princeton, NJ.

Anderson, Gary M. and Robert D. Tollison, 1983The myth of the corporation as a creation of the state, International Review of Law and Economics 3, 107-120.

Ball, Ray, S.P. Kothari, and Ashok Robin, 2000, The Effect of International Institutional Factors on Properties of Accounting Earnings, Journal of Accounting and Economics 29, 1-51.

Beck, Thorsten; Demirgüç-Kunt, Asli; Levine, Ross, 2000, “A New Database on the Structure and Development of the Financial Sector" The World Bank Economic Review 14, 597-605.

Beck, T., Demirguc-Kunt, A., and V. Maksimovic. 2004. "Financial and Legal Constraints to Firm Growth: Does Size Matter,” Journal of Finance, forthcoming.

Butler, Henry, N., General incorporation in nineteenth century England: Interaction of common law and legislative processes, International Review of Law and Economics, Volume 6, Issue 2, December 1986, Pages 169-188.

Carr Jack L., and G. Frank Mathewson, 1988, Unlimited liability as a barrier to entry, Journal of Political Economy 96, 766-784.

Claeessens, Stijn and Leora Klapper, 2003, "Bankruptcy Around the World: Explanations of its Relative Use", World Bank, Mimeo.

Demirgüç-Kunt, Asli, and Vojislav Maksimovic, 1998, Law, Finance, and Firm Growth, Journal of Finance 53, 2107-2137.

Djankov, Simeon, La Porta, R., Lopez-de-Silanes, F., Shleifer, A., 2002. “The Regulation of Entry",Quarterly Journal of Economics 117 (1):1-37.

Du Bois, A.B., 1971, The English Business Company After the Bubble Act, 1720-1800. New York, Octagon Books.

Easterbrook, Frank H. and Daniel R. Fischel, 1985, Limited Liability and the Corporation, University of Chicago Law Review 52, 89-117.

Ekelund, Robert B. and Robert D. Tollison, 1980, Mercantilist origin of the Corporation, The Bell Journal of Economics 11, 715-720.

Ekelund, Robert B. and Robert D. Tollison, 1983, Tradeable Shares and the Supply-Side of Corporate Development: Reply, The Bell Journal of Economics 14, 298-300. 
Fama, Eugene, and Michael Jensen, 1983a, Separation of ownership and control, Journal of Law and Economics, 26, 301-325.

Fama, Eugene, and Michael Jensen, 1983b, Agency problems and residual claims, Journal of Law and Economics, 26, 327-349.

Gomes A., 2000, Going public without governance: Managerial reputation effects, Journal of Finance $55,615-646$.

Goolsbee, Austan, 1998, Taxes, organizational form, and the deadweight loss of the corporate income tax, Journal of public Economics, 69, 143-152.

Gordon R., and J. Mackie-Mason, 1994, Taxes and the choice of organizational form, Journal of Public Economics 55, 279-306.

Gordon R., and J. Mackie-Mason, 1997, How much do taxes discourage incorporation? Journal of Finance 52, 477-505.

Hansmann, Henry, 1996, The ownership of enterprise, Harvard University Press.

Halperin, Paul, Trebilock Michael, and Stuart Turnbull, 1980, An economic analysis of limited liability in corporation law, University of Toronto Law Journal 30, 117-150.

Harhoff D., K. Stahl, and M. Woywode, 1998, Legal Form, Growth and Exit of West-German Firms Empirical Results for Manufacturing, Construction, Trade, and Service Industries, Journal of Industrial Economics 46,Hermalin, Benjamin E., 1994, Heterogeneity in organizational form: why otherwise identical firms choose different incentives for their managers, RAND Journal of Economics $25,518-537$.

Hung, Mingyi, 2001, Accounting Standards and Value Relevance of Financial Statements: An International Analysis, Journal of Accounting and Economics 30, 401-420.

John Kose, and Lemma Senbet, 1996, Corporate limited liability and the design of corporate taxation, New York University working paper

Laeven Luc and Christopher Woodruff, 2003, The Quality of the Legal System, Firm Ownership, and Firm Size, World Bank Working Paper.

La Porta, R., Lopez-de-Silanes, F., Shleifer, A., 2003, What Works in Securities Laws? Harvard University Working Paper.

La Porta, R., Lopez-de-Silanes, F., Shleifer, A., 2002, Corporate Ownership Around the World, Journal of Finance, 1999.

La Porta, R., Lopez-de-Silanes, F., Shleifer, A., and R.W. Vishny, 2000, Investor Protection and Corporate Governance, Journal of Financial Economics. 
La Porta, R., Lopez-de-Silanes, F., Shleifer, A., and R.W. Vishny, 1998. “Law and Finance”,Journal of Political Economy 106, 1113-1155.

Levin, Jonathan, and Steven Tadelis, 2002, A theory of partnerships, Working Paper, Department of Economics, Stanford, CA.

Maksimovic Vojislav and Josef Zechner, 1991, Debt, agency, and industry equilibrium Journal of Finance 46, 1619-1644.

McNulty, Paul and Guiio Pontecorvo, 1983, Mercantilist origin of the Corporation: Comment, The Bell Journal of Economics 14, 294-297.

Miller, Merton, 1977, Debt and taxes, Journal of Finance 32, 261-275.

Miwa, Yoshiro and J. Mark Rameyser, 2000, Corporate Governance in Transitional Economies: Lessons from the Prewar Japanese Cotton Textile Industry, Journal of Legal Studies, 171-203.

Morrison, Alan. D, and William J. Wilhelm, 2003, Partnership Firms, Reputation and Human Capital, mimeo, Said Business School, University of Oxford, UK.

Senbet, Lemmaand Seward (1995), Financial distress, bankruptcy and reorganization, in Jarrow, R.A., V. Maksimovic and W.T. Ziemba (editors). Handbooks in Operations Research and Management Science, Volume 9: Finance. Amsterdam: Elsevier-North Holland.

Shannon, Herbert A., 1931, The coming of general limited liability, Economic History 2, January 267-291. Reissued in E. M. Carus-Wilson, ed., Essays in Economic History, Vol. I (London, 1954), pp. $358-79$

Shannon, Herbert A., 'The Limited Companies of 1866 - 1883,' Economic History Review, 1st ser. 4 (1933), reissued in E. M. Carus-Wilson, ed., Essays in Economic History,Vol. I (London, 1954), pp. $380-405$.

Winton, Andrew, 1993, Limitation of Liability and the Owner Structure of the Firm, Journal of Finance 48, 487-512.

World Bank, 2004, "Doing Business in 2004: Understanding Regulation” The World Bank, Washington D.C. 


\section{Table I}

\section{Descriptive Statistics}

\section{Panel A. Proportion of Corporations and Country-level variables}

GDPPC is real GDP per capita, Financial Development equals to sum of credit to the private sector and market capitalization to GDP, Law and Order is a measure of the law and order tradition of a country, Corruption is a measure of corruption, Tax disadvantage equals to the difference of maximum of corporate tax rate minus maximum personal tax rate, Shareholder Rights is an index of shareholder rights from LLSV (1998), Creditor Rights is an index of creditor rights from LLSV (1998), Duration of Entry is the time it takes to obtain legal status to operate a firm with limited liability involved in industrial or commercial activity, in business days, Percent of Bankruptcies is the ratio of the number of bankruptcies per year over the total number of registered firms in a country in that year, Time in Bankruptcy is the average duration of insolvency procedures for a standardize bankruptcy case, in number of years, Absolute Priority documents the order in which claims are paid in the insolvency process. See Table A1 for more detailed definitions and sources.

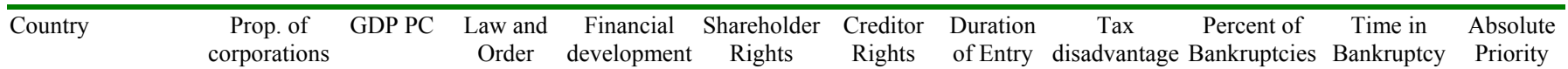

\begin{tabular}{|c|c|c|c|c|c|c|c|c|c|c|c|}
\hline Albania & 0.26 & 807 & 2.95 & . & $* * 3$ & 3 & 62 & 0 & . & 2.01 & 0.67 \\
\hline Argentina & 0.79 & 8,000 & 5 & 0.37 & 4 & 1 & 62 & 0 & 0.12 & 2.82 & 0.67 \\
\hline Armenia & 0.57 & 844 & 4 & 0.06 & 5.5 & 3 & 79 & -5 & . & 1.94 & 1 \\
\hline Belarus & 0.48 & 2,235 & 4 & 0.06 & 1.5 & 2 & 121 & 0 & . & 2.18 & 0 \\
\hline Bolivia & 0.02 & 939 & 3 & 0.48 & . & . & 104 & 12 & . & 2.02 & 1 \\
\hline Brazil & 0.31 & 4,492 & 2.05 & 0.53 & 3 & 1 & 86 & -12.5 & . & 10 & 0.33 \\
\hline Canada & 0.64 & 20,549 & 6 & 1.41 & 5 & 1 & 2 & 15.6 & 2.96 & 0.8 & 1 \\
\hline Chile & 0.2 & 5,003 & 5 & 1.51 & 5 & 2 & 34 & -30 & 0.28 & 5.84 & 0 \\
\hline China & 0.56 & 677 & 5 & 0.97 & . & . & 55 & -15 & . & 2.62 & 1 \\
\hline Colombia & 0.16 & 2,381 & 2 & 0.39 & 3 & 0 & 59 & 0 & 0.16 & 3.03 & 0.33 \\
\hline Costa Rica & 0.63 & 3,692 & 4 & 0.24 & . & . & 80 & 5 & . & 2.51 & 0.67 \\
\hline Ecuador & 0.37 & 1,538 & 3.36 & 0.36 & 2 & 4 & 90 & -25 & . & 3.5 & 0 \\
\hline El Salvador & 0.17 & 1,706 & 3 & 0.37 & . & . & . & -5 & . & . & . \\
\hline Estonia & 0.39 & 3,663 & 4 & 0.16 & 3.75 & 4 & . & 0 & . & . & . \\
\hline France & 0.89 & 27,720 & 5 & 1.27 & 3 & 0 & 53 & -19.42 & 2.62 & 2.39 & 0.67 \\
\hline Germany & 0.36 & 30,794 & 6 & 1.38 & 1 & 3 & 45 & -13 & 1.03 & 1.18 & 1 \\
\hline Guatemala & 0.44 & 1,503 & 2.14 & 0.16 & . & . & 41 & 2.5 & . & 4 & 0.67 \\
\hline Haiti & 0.2 & 369 & 2.59 & 0.12 & . & . & . & 5 & . & . & . \\
\hline Honduras & 0.1 & 708 & 2.05 & 0.27 & . & . & 146 & -10 & . & 3.76 & 0.67 \\
\hline Hungary & 0.91 & 4,706 & 6 & 0.29 & 3 & 3.75 & 65 & -22 & 1.99 & 2 & 0.67 \\
\hline Indonesia & 0.34 & 1,045 & 2.64 & 0.8 & 2 & 4 & 158 & 0 & . & 6 & 0.67 \\
\hline
\end{tabular}




\begin{tabular}{|c|c|c|c|c|c|c|c|c|c|c|c|}
\hline Nicaragua & 0.18 & 435 & 4 & 0.31 & . & . & 68 & 0 & . & 2.27 & 1 \\
\hline Pakistan & 0.5 & 506 & 3.14 & 0.41 & 5 & 4 & 69 & 10 & . & 2.77 & 1 \\
\hline Panama & 0.48 & 3,124 & 3 & 0.92 & . & . & 19 & 0 & . & 6.5 & 1 \\
\hline Peru & 0.3 & 2,335 & 3 & 0.38 & 3 & 0 & 114 & 0 & 0.05 & 2.09 & 0.33 \\
\hline Philippines & 0.79 & 1,126 & 4 & 1.14 & 3 & 0 & 62 & 0 & . & 5.71 & 1 \\
\hline Poland & 0.02 & 3,216 & 5 & 0.16 & 3 & 2.25 & 58 & -6 & 0.23 & 1.53 & 0.67 \\
\hline Portugal & 0.58 & 11,582 & 5 & 1.03 & 3 & 1 & 104 & -2.6 & 0.08 & 2.55 & 0.33 \\
\hline Romania & 0.14 & 1,372 & 4.77 & 0.1 & 3 & 4 & 46 & -7 & . & 3.21 & 0.33 \\
\hline Russia & 0.66 & 2,224 & 3.45 & 0.17 & 5.5 & 2.5 & 50 & 0 & 0.31 & 1.53 & 0.67 \\
\hline Singapore & 0.88 & 24,948 & 6 & 2.37 & 4 & 4 & 8 & -2 & 3.06 & 0.71 & 1 \\
\hline Slovak Rep. & 0.55 & 3,805 & 5 & 0.38 & 2.5 & 4 & 125 & -2 & . & 4.75 & 1 \\
\hline Slovenia & 0.42 & 10,233 & 5 & 0.29 & 2.5 & 4 & 62 & 10 & . & 1.43 & 0.67 \\
\hline Sweden & 0.98 & 28,258 & 6 & 1.35 & 3 & 2 & 18 & -32 & 7.61 & 2 & 1 \\
\hline Trinidad \& Tobago & 0.61 & 4,526 & 4 & 0.55 & . & . & . & 0 & . & . & . \\
\hline Turkey & 0.48 & 2,994 & 3.91 & 0.33 & 2 & 2 & 53 & -10 & 0.86 & 1.8 & 0.67 \\
\hline USA & 0.77 & 29,250 & 6 & 1.79 & 5 & 1 & 4 & -0.6 & 1.34 & 3 & 1 \\
\hline Ukraine & 0.65 & 867 & 4 & 0.02 & 2.5 & 4 & 42 & -10 & . & 2.97 & 0.67 \\
\hline United Kingdom & 0.5 & 20,187 & 6 & 2.57 & 5 & 4 & 4 & -10 & 1.85 & 1.04 & 1 \\
\hline Uruguay & 0.03 & 6,114 & 3 & 0.28 & 2 & 2 & 27 & 30 & . & 4 & 1 \\
\hline Venezuela & 0.93 & 3,483 & 4 & 0.19 & 1 & . & 124 & 0 & . & 4.04 & 1 \\
\hline All Sample & 0.49 & 6,134 & 4.19 & 0.56 & 3.41 & 2.74 & 62.86 & -3.99 & 1.29 & 3.03 & 0.72 \\
\hline
\end{tabular}




\section{Panel B. Firm-Level Variables}

Foreign is a dummy for foreign ownership, Exporter is a dummy for exporters, Manufacturing and Service are industry dummies, Small and Medium are size dummies, Obstacles are measured on a scale from 1 (no obstacle) to 4 (major obstacle). See Table A1 for more detailed definitions and sources.

\begin{tabular}{|c|c|c|c|c|c|c|c|c|c|c|c|c|}
\hline \multirow[b]{2}{*}{ Country } & \multicolumn{6}{|c|}{ Percent of firms that are: } & \multirow[b]{2}{*}{$\begin{array}{l}\text { Log of } \\
\text { Age }\end{array}$} & \multicolumn{4}{|c|}{ Average Obstacles } & \multirow[b]{2}{*}{$\begin{array}{l}\text { Sales } \\
\text { growth }\end{array}$} \\
\hline & Foreign $\mathrm{E}$ & rter & $\begin{array}{l}\text { Manufact } \\
\text { uring }\end{array}$ & Service & Small & Medium & & Financing & Corruption & Legal & $\begin{array}{l}\text { Taxes and } \\
\text { Regulations }\end{array}$ & \\
\hline Albania & 0.13 & 0.17 & 0.27 & 0.60 & 0.79 & 0.21 & 1.55 & 2.82 & 2.14 & 2.78 & 3.24 & 0.19 \\
\hline Argentina & 0.35 & 0.30 & 0.34 & 0.52 & 0.31 & 0.48 & 2.90 & 3.01 & 1.55 & 2.37 & 3.38 & 0.09 \\
\hline Armenia & 0.01 & 0.03 & 0.15 & 0.74 & 0.80 & 0.17 & 1.66 & 2.52 & 1.11 & 1.44 & 3.50 & -0.22 \\
\hline Azerbaijan & 0.02 & 0.03 & 0.28 & 0.49 & 0.76 & 0.24 & 1.37 & 2.93 & 2.87 & 2.38 & 2.98 & -0.20 \\
\hline Bolivia & 0.15 & 0.44 & 0.58 & 0.38 & 0.33 & 0.47 & 2.72 & 3.31 & 1.80 & 2.66 & 3.16 & 0.03 \\
\hline Brazil & 0.25 & 0.31 & 0.32 & 0.61 & 0.14 & 0.71 & 3.28 & 2.71 & 1.27 & 2.57 & 3.58 & 0.04 \\
\hline Bulgaria & 0.05 & 0.14 & 0.41 & 0.33 & 0.86 & 0.14 & 1.83 & 3.22 & 2.51 & 2.12 & 3.22 & 0.03 \\
\hline Canada & 0.21 & 0.47 & 0.28 & 0.64 & 0.25 & 0.54 & 3.18 & 2.13 & 1.08 & 1.48 & 2.61 & 0.16 \\
\hline Chile & 0.27 & 0.37 & 0.43 & 0.53 & 0.57 & 0.23 & 3.14 & 2.57 & 1.22 & 1.76 & 2.27 & 0.00 \\
\hline Croatia & 0.13 & 0.66 & 0.46 & 0.53 & 0.32 & 0.52 & 3.14 & 3.22 & 1.76 & 2.69 & 3.25 & 0.01 \\
\hline Czech Rep. & 0.17 & 0.28 & 0.16 & 0.74 & 0.82 & 0.15 & 1.90 & 3.11 & 2.00 & 2.10 & 3.31 & 0.02 \\
\hline Dominican Rep. & 0.30 & 0.51 & 0.67 & 0.23 & 0.14 & 0.33 & 2.87 & 2.51 & 1.38 & 2.42 & 2.98 & 0.22 \\
\hline Ecuador & 0.18 & 0.29 & 0.49 & 0.43 & 0.24 & 0.51 & 2.99 & 3.23 & 2.81 & 3.10 & 3.00 & -0.04 \\
\hline El Salvador & 0.00 & 0.17 & 0.67 & 0.33 & 0.67 & 0.00 & 3.14 & 3.17 & 1.00 & 3.33 & 3.17 & -0.37 \\
\hline Estonia & 0.21 & 0.59 & 0.35 & 0.53 & 0.56 & 0.38 & 2.01 & 2.52 & 1.44 & 1.67 & 2.70 & 0.29 \\
\hline France & 0.23 & 0.44 & 0.39 & 0.56 & 0.43 & 0.39 & 2.79 & 2.78 & 1.29 & 1.76 & 3.23 & 0.23 \\
\hline Germany & 0.31 & 0.36 & 0.20 & 0.64 & 0.25 & 0.61 & 2.91 & 2.53 & 1.55 & 1.99 & 3.02 & 0.11 \\
\hline Guatemala & 0.14 & 0.23 & 0.35 & 0.51 & 0.47 & 0.35 & 2.63 & 3.00 & 1.58 & 2.38 & 2.63 & 0.18 \\
\hline Kyrgyz Rep. & 0.10 & 0.16 & 0.33 & 0.31 & 0.44 & 0.53 & 1.56 & 3.39 & 2.75 & 2.30 & 3.64 & 0.00 \\
\hline Lithuania & 0.06 & 0.29 & 0.19 & 0.68 & 0.84 & 0.13 & 1.75 & 2.87 & 2.16 & 2.15 & 3.28 & -0.08 \\
\hline Malaysia & 0.17 & 0.43 & 0.56 & 0.36 & 0.51 & 0.32 & 2.36 & 2.31 & 1.76 & 1.66 & 1.87 & 0.01 \\
\hline Moldova & 0.00 & 0.22 & 0.26 & 0.38 & 0.49 & 0.47 & 1.60 & 3.51 & 2.24 & 2.40 & 3.46 & -0.22 \\
\hline Nicaragua & 0.10 & 0.06 & 0.49 & 0.39 & 0.69 & 0.22 & 2.43 & 3.29 & 2.46 & 2.39 & 3.21 & 0.15 \\
\hline Pakistan & 0.17 & 0.49 & 0.51 & 0.47 & 0.40 & 0.41 & 2.48 & 3.28 & 2.49 & 2.61 & 3.21 & 0.07 \\
\hline Panama & 0.22 & 0.43 & 0.30 & 0.65 & 0.26 & 0.35 & 3.13 & 2.09 & 1.43 & 2.43 & 2.52 & 0.11 \\
\hline Peru & 0.16 & 0.11 & 0.38 & 0.43 & 0.43 & 0.27 & 2.49 & 2.97 & 2.44 & 2.35 & 3.30 & -0.10 \\
\hline Philippines & 0.22 & 0.32 & 0.44 & 0.54 & 0.27 & 0.53 & 2.87 & 2.69 & 2.17 & 2.28 & 3.11 & 0.07 \\
\hline Poland & 0.07 & 0.34 & 0.19 & 0.63 & 0.57 & 0.37 & 2.16 & 2.33 & 1.44 & 2.16 & 3.11 & 0.15 \\
\hline Portugal & 0.30 & 0.25 & 0.26 & 0.69 & 0.40 & 0.36 & 2.98 & 1.68 & 1.47 & 1.77 & 1.99 & 0.12 \\
\hline
\end{tabular}




\begin{tabular}{|c|c|c|c|c|c|c|c|c|c|c|c|c|}
\hline Romania & 0.19 & 0.16 & 0.46 & 0.51 & 0.78 & 0.16 & 1.77 & 3.22 & 2.10 & 2.67 & 3.63 & -0.02 \\
\hline Russia & 0.02 & 0.08 & 0.28 & 0.41 & 0.42 & 0.51 & 1.70 & 3.22 & 1.79 & 2.07 & 3.54 & 0.06 \\
\hline Singapore & 0.36 & 0.47 & 0.31 & 0.53 & 0.37 & 0.31 & 2.87 & 1.88 & 1.24 & 1.32 & 1.53 & 0.11 \\
\hline Slovak Republic & 0.06 & 0.51 & 0.27 & 0.60 & 0.67 & 0.31 & 1.84 & 3.37 & 2.00 & 2.11 & 3.32 & 0.04 \\
\hline Slovenia & 0.16 & 0.78 & 0.51 & 0.32 & 0.36 & 0.59 & 2.37 & 2.30 & 1.28 & 2.32 & 2.86 & 0.21 \\
\hline Sweden & 0.25 & 0.57 & 0.33 & 0.48 & 0.51 & 0.39 & 3.22 & 1.85 & 1.06 & 1.54 & 2.66 & 0.25 \\
\hline Trinidad \& Tobago & 0.18 & 0.58 & 0.45 & 0.39 & 0.45 & 0.39 & 2.97 & 3.05 & 1.82 & 1.41 & 2.86 & 0.19 \\
\hline Turkey & 0.11 & 0.44 & 0.44 & 0.29 & 0.44 & 0.49 & 2.53 & 3.19 & 2.40 & 2.32 & 3.24 & -0.03 \\
\hline USA & 0.09 & 0.29 & 0.22 & 0.65 & 0.46 & 0.32 & 3.16 & 2.23 & 1.43 & 1.72 & 2.45 & 0.14 \\
\hline Ukraine & 0.04 & 0.22 & 0.39 & 0.46 & 0.57 & 0.37 & 1.50 & 3.37 & 1.93 & 2.03 & 3.65 & -0.06 \\
\hline U.K. & 0.15 & 0.27 & 0.24 & 0.53 & 0.70 & 0.26 & 2.62 & 2.32 & 1.03 & 1.52 & 3.00 & 0.28 \\
\hline Uruguay & 0.13 & 0.49 & 0.62 & 0.31 & 0.23 & 0.62 & 3.10 & 2.67 & 1.13 & 1.75 & 3.10 & 0.05 \\
\hline Venezuela & 0.71 & 0.57 & 0.50 & 0.50 & 0.21 & 0.00 & 3.13 & 1.86 & 1.23 & 3.00 & 2.79 & 0.14 \\
\hline All Sample & 0.15 & 0.32 & 0.34 & 0.51 & 0.48 & 0.39 & 2.30 & 2.83 & 1.78 & 2.10 & 3.09 & 0.07 \\
\hline
\end{tabular}

Panel C. Correlations of Proportion of Corporations and Country-level variables

\begin{tabular}{|c|c|c|c|c|c|c|c|c|c|}
\hline & $\begin{array}{l}\text { Proportion of } \\
\text { corporations }\end{array}$ & $\begin{array}{l}\text { Law and } \\
\text { Order }\end{array}$ & $\begin{array}{l}\text { Financial } \\
\text { development }\end{array}$ & $\begin{array}{l}\text { Shareholder } \\
\text { Rights }\end{array}$ & $\begin{array}{l}\text { Creditor } \\
\text { Rights }\end{array}$ & $\begin{array}{l}\text { Duration of } \\
\text { Entry }\end{array}$ & $\begin{array}{l}\text { Tax } \\
\text { disadvantage }\end{array}$ & $\begin{array}{l}\text { Percent of } \\
\text { Bankruptcies }\end{array}$ & $\begin{array}{l}\text { Time in } \\
\text { Bankruptcy }\end{array}$ \\
\hline Law and Order & $0.21 *$ & & & & & & & & \\
\hline Shareholder Rights & $0.14 *$ & $-0.06^{*}$ & $0.11 *$ & & & & & & \\
\hline Creditor Rights & $-0.05^{*}$ & $0.15^{*}$ & $-0.11 *$ & $-0.09 *$ & & & & & \\
\hline Duration of Entry & $-0.18^{*}$ & $-0.41^{*}$ & $-0.29^{*}$ & $-0.40^{*}$ & $0.07 *$ & & & & \\
\hline Percent of Bankruptcies & $0.27 *$ & $0.55^{*}$ & $0.52 *$ & $-0.15^{*}$ & $0.09 *$ & $-0.49^{*}$ & $-0.49^{*}$ & & \\
\hline Time in Bankruptcy & $-0.12 *$ & $-0.35^{*}$ & $-0.04 *$ & $-0.22 *$ & $-0.16^{*}$ & $0.35^{*}$ & $-0.13 *$ & -0.03 & \\
\hline Absolute Priority & $0.12 *$ & $0.32 *$ & $0.28 *$ & $0.21 *$ & $0.19^{*}$ & $-0.34 *$ & $0.24 *$ & $0.56^{*}$ & -0.23 \\
\hline
\end{tabular}


Table II

\section{Predicting the Choice of Incorporation}

Dependent variable is a corporation dummy that equals to one if a firm is registered as a corporation and zero otherwise (i.e. partnership or sole proprietorship). Foreign is a dummy for foreign ownership, Exporter is a dummy for exporters, Manufacturing and Service are industry dummies, Small and Medium are size dummies, Obstacles are measured on a scale from 1 (no obstacle) to 4 (major obstacle). GDPPC is real GDP per capita, Financial Development equals to sum of credit to the private sector and market capitalization to GDP, Law and Order is a measure of the law and order tradition of a country, Tax disadvantage equals to the difference of maximum of corporate tax rate minus maximum personal tax rate, Shareholder Rights is an index of shareholder rights from LLSV (1998), Creditor Rights is an index of creditor rights from LLSV (1998), Legal origin are dummy variables indicating French or Socialist orgin,Duration of Entry is the time it takes to obtain legal status to operate a firm with limited liability involved in industrial or commercial activity, in business days, Percent of Bankruptcies is the ratio of the number of bankruptcies per year over the total number of registered firms in a country in that year, Time in Bankruptcy is the average duration of insolvency procedures for a standardize bankruptcy case, in number of years, Absolute Priority documents the order in which claims are paid in the insolvency process. Institutions is an index equal to first principal component of Law and Order, Financial Development, Corruption, Duration of Entry, and Time in Bankruptcy. See Table Al for more detailed definitions and sources. All models are estimated by logit with heteroskedasticity robust standard errors.

\begin{tabular}{|c|c|c|c|c|c|c|c|c|c|c|c|}
\hline & (1) & (2) & (3) & (4) & (5) & (6) & (7) & (8) & (9) & (10) & (11) \\
\hline Foreign ownership & $\begin{array}{l}0.562 \\
{[0.000]^{* * *}}\end{array}$ & $\begin{array}{l}0.523 \\
{[0.000]^{* * *}}\end{array}$ & $\begin{array}{l}0.607 \\
{[0.000]^{* * *}}\end{array}$ & $\begin{array}{l}0.639 \\
{[0.000]^{* * *}}\end{array}$ & $\begin{array}{l}0.674 \\
{[0.000]^{* * *}}\end{array}$ & $\begin{array}{l}0.633 \\
{[0.000]^{* * *}}\end{array}$ & $\begin{array}{l}0.546 \\
{[0.000]^{* * *}}\end{array}$ & $\begin{array}{l}0.813 \\
{[0.000]^{* * *}}\end{array}$ & $\begin{array}{l}0.635 \\
{[0.000]^{* * *}}\end{array}$ & $\begin{array}{l}0.648 \\
{[0.000]^{* * *}}\end{array}$ & $\begin{array}{l}0.596 \\
{[0.000]^{* * *}}\end{array}$ \\
\hline Exporter dummy & $\begin{array}{l}0.13 \\
{[0.107]}\end{array}$ & $\begin{array}{l}0.112 \\
{[0.170]}\end{array}$ & $\begin{array}{l}0.072 \\
{[0.389]}\end{array}$ & $\begin{array}{l}0.136 \\
{[0.122]}\end{array}$ & $\begin{array}{l}0.068 \\
{[0.408]}\end{array}$ & $\begin{array}{l}0.144 \\
{[0.094]^{*}}\end{array}$ & $\begin{array}{l}0.153 \\
{[0.061]^{*}}\end{array}$ & $\begin{array}{l}-0.415 \\
{[0.003]^{* * *}}\end{array}$ & $\begin{array}{l}0.114 \\
{[0.185]}\end{array}$ & $\begin{array}{l}0.063 \\
{[0.462]}\end{array}$ & $\begin{array}{l}0.054 \\
{[0.541]}\end{array}$ \\
\hline Manufacturing & $\begin{array}{l}-0.133 \\
{[0.204]}\end{array}$ & $\begin{array}{l}-0.202 \\
{[0.063]^{*}}\end{array}$ & $\begin{array}{l}-0.115 \\
{[0.287]}\end{array}$ & $\begin{array}{l}0.021 \\
{[0.848]}\end{array}$ & $\begin{array}{l}-0.048 \\
{[0.652]}\end{array}$ & $\begin{array}{l}-0.148 \\
{[0.177]}\end{array}$ & $\begin{array}{l}-0.138 \\
{[0.195]}\end{array}$ & $\begin{array}{l}0.131 \\
{[0.417]}\end{array}$ & $\begin{array}{l}-0.135 \\
{[0.214]}\end{array}$ & $\begin{array}{l}-0.142 \\
{[0.188]}\end{array}$ & $\begin{array}{l}-0.238 \\
{[0.040]^{* *}}\end{array}$ \\
\hline Services & $\begin{array}{l}-0.288 \\
{[0.003]^{* * *}}\end{array}$ & $\begin{array}{l}-0.315 \\
{[0.002]^{* * *}}\end{array}$ & $\begin{array}{l}-0.271 \\
{[0.006]^{* * *}}\end{array}$ & $\begin{array}{l}-0.206 \\
{[0.043]^{* *}}\end{array}$ & $\begin{array}{l}-0.205 \\
{[0.036]^{* *}}\end{array}$ & $\begin{array}{l}-0.259 \\
{[0.010]^{* *}}\end{array}$ & $\begin{array}{l}-0.295 \\
{[0.003]^{* * *}}\end{array}$ & $\begin{array}{l}-0.45 \\
{[0.002]^{* * *}}\end{array}$ & $\begin{array}{l}-0.234 \\
{[0.019]^{* *}}\end{array}$ & $\begin{array}{l}-0.309 \\
{[0.002]^{* * *}}\end{array}$ & $\begin{array}{l}-0.303 \\
{[0.004]^{* * *}}\end{array}$ \\
\hline Log of firm age & $\begin{array}{l}-0.061 \\
{[0.122]}\end{array}$ & $\begin{array}{l}-0.082 \\
{[0.039]^{* *}}\end{array}$ & $\begin{array}{l}0.012 \\
{[0.768]}\end{array}$ & $\begin{array}{l}0.066 \\
{[0.142]}\end{array}$ & $\begin{array}{l}0.077 \\
{[0.080]^{*}}\end{array}$ & $\begin{array}{l}-0.051 \\
{[0.218]}\end{array}$ & $\begin{array}{l}-0.058 \\
{[0.145]}\end{array}$ & $\begin{array}{l}-0.016 \\
{[0.801]}\end{array}$ & $\begin{array}{l}-0.017 \\
{[0.680]}\end{array}$ & $\begin{array}{l}-0.073 \\
{[0.073]^{*}}\end{array}$ & $\begin{array}{l}-0.038 \\
{[0.365]}\end{array}$ \\
\hline Small & $\begin{array}{l}-1.554 \\
{[0.000]^{* * *}}\end{array}$ & $\begin{array}{l}-1.533 \\
{[0.000]^{* * *}}\end{array}$ & $\begin{array}{l}-1.717 \\
{[0.000]^{* * *}}\end{array}$ & $\begin{array}{l}-1.57 \\
{[0.000]^{* * *}}\end{array}$ & $\begin{array}{l}-1.714 \\
{[0.000]^{* * *}}\end{array}$ & $\begin{array}{l}-1.629 \\
{[0.000]^{* * *}}\end{array}$ & $\begin{array}{l}-1.607 \\
{[0.000]^{* * *}}\end{array}$ & $\begin{array}{l}-1.539 \\
{[0.000]^{* * *}}\end{array}$ & $\begin{array}{l}-1.574 \\
{[0.000]^{* * *}}\end{array}$ & $\begin{array}{l}-1.718 \\
{[0.000]^{* * *}}\end{array}$ & $\begin{array}{l}-1.668 \\
{[0.000]^{* * *}}\end{array}$ \\
\hline Medium & $\begin{array}{l}-0.615 \\
{[0.000]^{* * *}}\end{array}$ & $\begin{array}{l}-0.614 \\
{[0.000]^{* * *}}\end{array}$ & $\begin{array}{l}-0.651 \\
{[0.000]^{* * *}}\end{array}$ & $\begin{array}{l}-0.608 \\
{[0.000]^{* * *}}\end{array}$ & $\begin{array}{l}-0.705 \\
{[0.000]^{* * *}}\end{array}$ & $\begin{array}{l}-0.701 \\
{[0.000]^{* * *}}\end{array}$ & $\begin{array}{l}-0.64 \\
{[0.000]^{* * *}}\end{array}$ & $\begin{array}{l}-0.54 \\
{[0.004]^{* * *}}\end{array}$ & $\begin{array}{l}-0.622 \\
{[0.000]^{* * *}}\end{array}$ & $\begin{array}{l}-0.716 \\
{[0.000]^{* * *}}\end{array}$ & $\begin{array}{l}-0.671 \\
{[0.000]^{* * *}}\end{array}$ \\
\hline Log GDP PC & $\begin{array}{l}0.312 \\
{[0.000]^{* * *}}\end{array}$ & $\begin{array}{l}0.213 \\
{[0.000]^{* * *}}\end{array}$ & $\begin{array}{l}0.042 \\
{[0.291]}\end{array}$ & $\begin{array}{l}0.26 \\
{[0.000]^{* * *}}\end{array}$ & $\begin{array}{l}0.276 \\
{[0.000]^{* * *}}\end{array}$ & $\begin{array}{l}0.181 \\
{[0.000]^{* * *}}\end{array}$ & $\begin{array}{l}0.283 \\
{[0.000] * * *}\end{array}$ & $\begin{array}{l}-0.049 \\
{[0.539]}\end{array}$ & $\begin{array}{l}0.256 \\
{[0.000]^{* * *}}\end{array}$ & $\begin{array}{l}0.273 \\
{[0.000]^{* * *}}\end{array}$ & $\begin{array}{l}-0.097 \\
{[0.043]^{* *}}\end{array}$ \\
\hline Financial Development & & $\begin{array}{l}0.158 \\
{[0.008]^{* * *}}\end{array}$ & & & & & & & & & \\
\hline Law and Order & & & $\begin{array}{l}0.434 \\
{[0.000]^{* * *}}\end{array}$ & & & & & & & & \\
\hline Shareholder rights & & & & $\begin{array}{l}0.32 \\
{[0.000]^{* * *}}\end{array}$ & & & & & & & \\
\hline Creditor rights & & & & $\begin{array}{l}0.126 \\
{[0.000]^{* * *}}\end{array}$ & & & & & & & \\
\hline Legal origin - Socialist & & & & & $\begin{array}{l}0.042 \\
{[0.719]}\end{array}$ & & & & & & \\
\hline Legal origin - French & & & & & $\begin{array}{l}-0.732 \\
{[0.000]^{* * *}}\end{array}$ & & & & & & \\
\hline Duration of Entry & & & & & & $\begin{array}{l}-0.01 \\
{[0.000]^{* * *}}\end{array}$ & & & & & \\
\hline Tax Disadvantage & & & & & & & $\begin{array}{l}-0.022 \\
{[0.000]^{* * *}}\end{array}$ & & & & \\
\hline Percent of Bankruptcies & & & & & & & & $\begin{array}{l}0.65 \\
{[0.000]^{* * *}}\end{array}$ & & & \\
\hline Time in Bankruptcy & & & & & & & & & $\begin{array}{l}-0.122 \\
{[0.000]^{* * *}}\end{array}$ & & \\
\hline Absolute Priority & & & & & & & & & & $\begin{array}{l}1.199 \\
{[0.000]^{* * *}}\end{array}$ & \\
\hline Institutions & & & & & & & & & & & $\begin{array}{l}0.336 \\
{[0.000]^{* * *}}\end{array}$ \\
\hline Number of Observations & 4212 & 3948 & 4142 & 3746 & 4212 & 3912 & 4142 & 1784 & 3939 & 3982 & 3605 \\
\hline Number of Countries & 53 & 50 & 52 & 41 & 53 & 48 & 52 & 18 & 48 & 49 & 44 \\
\hline
\end{tabular}




\section{Table III \\ Firm Incorporation and Obstacles}

Dependent variables are Financing Obstacle in models (1) and (2), Legal Obstacle in models (3) and (4), Corruption Obstacle in models (5) and (6), Taxes and Regulations obstacle in models (7) and (8). Each obstacle is measured on a scale (1) - "no obstacle" to (4) - "major obstacle". Foreign is a dummy for foreign ownership, Exporter is a dummy for exporters, Manufacturing and Service are industry dummies, Small and Medium are size dummies, GDPPC is real GDP per capita, Financial Development equals to sum of credit to the private sector and market capitalization to GDP, Law and Order is a measure of the law and order tradition of a country, Corruption is a measure of corruption, Tax disadvantage equals to the difference of maximum of corporate tax rate minus maximum personal tax rate, Shareholder Rights is an index of shareholder rights from LLSV (1998), Creditor Rights is an index of creditor rights from LLSV (1998), Duration of Entry is the time it takes to obtain legal status to operate a firm with limited liability involved in industrial or commercial activity, in business days, Percent of Bankruptcies is the ratio of the number of bankruptcies per year over the total number of registered firms in a country in that year, Time in Bankruptcy is the average duration of insolvency procedures for a standardize bankruptcy case, in number of years, Absolute Priority documents the order in which claims are paid in the insolvency process. See Table A1 for more detailed definitions and sources. All models are estimated by ordered probit with heteroskedasticity robust standard errors.

\begin{tabular}{|c|c|c|c|c|c|c|c|c|}
\hline \multirow[t]{2}{*}{ Dependent variable: } & \multicolumn{2}{|c|}{ Financing Obstacle } & \multicolumn{2}{|c|}{$\underline{\text { Legal Obstacle }}$} & \multicolumn{2}{|c|}{ Corruption Obstacle } & \multicolumn{2}{|c|}{$\frac{\text { Taxes and Regulations }}{\text { Obstacle }}$} \\
\hline & (1) & $(2)$ & (3) & (4) & (5) & (6) & (7) & (8) \\
\hline \multirow[t]{2}{*}{ Foreign ownership dummy } & -0.359 & -0.355 & 0.045 & 0.044 & 0.021 & 0.027 & -0.258 & -0.274 \\
\hline & {$[0.000]^{* * *}$} & {$[0.000]^{* * *}$} & {$[0.363]$} & {$[0.381]$} & {$[0.692]$} & {$[0.621]$} & {$[0.000] * * *$} & {$[0.000]^{* * *}$} \\
\hline \multirow[t]{2}{*}{ Exporter dummy } & 0.091 & 0.094 & 0.103 & 0.106 & 0.034 & 0.036 & -0.066 & -0.058 \\
\hline & {$[0.031]^{* *}$} & {$[0.026]^{* *}$} & {$[0.014]^{* *}$} & {$[0.012]^{* *}$} & {$[0.415]$} & {$[0.390]$} & {$[0.125]$} & [0.183] \\
\hline \multirow[t]{2}{*}{ Manufacturing } & -0.165 & -0.166 & -0.106 & -0.105 & -0.128 & -0.126 & -0.054 & -0.054 \\
\hline & {$[0.004]^{* * *}$} & {$[0.004] * * *$} & {$[0.067]^{*}$} & {$[0.069]^{*}$} & {$[0.026]^{* *}$} & {$[0.029]^{* *}$} & {$[0.350]$} & {$[0.352]$} \\
\hline \multirow[t]{2}{*}{ Services } & -0.362 & -0.363 & -0.059 & -0.058 & -0.129 & -0.125 & -0.124 & -0.126 \\
\hline & {$[0.000]^{* * *}$} & {$[0.000]^{* * *}$} & {$[0.272]$} & {$[0.280]$} & {$[0.017]^{* *}$} & {$[0.022]^{* *}$} & {$[0.019]^{* *}$} & {$[0.017]^{* *}$} \\
\hline \multirow[t]{2}{*}{ Log of firm age } & -0.07 & -0.069 & 0.101 & 0.104 & 0.099 & 0.1 & -0.044 & -0.038 \\
\hline & {$[0.001] * * *$} & {$[0.001]^{* * *}$} & {$[0.000]^{* * *}$} & {$[0.000]^{* * *}$} & {$[0.000]^{* * *}$} & {$[0.000] * * *$} & {$[0.037]^{* *}$} & {$[0.078]^{*}$} \\
\hline \multirow[t]{2}{*}{ Small } & 0.189 & 0.189 & -0.073 & -0.072 & 0.108 & 0.11 & 0.093 & 0.112 \\
\hline & {$[0.003]^{* * *}$} & {$[0.003]^{* * *}$} & {$[0.243]$} & {$[0.253]$} & {$[0.098]^{*}$} & {$[0.093]^{*}$} & {$[0.152]$} & {$[0.085]^{*}$} \\
\hline \multirow[t]{2}{*}{ Medium } & 0.155 & 0.152 & 0.017 & 0.018 & 0.095 & 0.092 & 0.304 & 0.316 \\
\hline & {$[0.008] * * *$} & {$[0.009] * * *$} & {$[0.756]$} & {$[0.739]$} & {$[0.108]$} & {$[0.121]$} & {$[0.000] * * *$} & {$[0.000]^{* * *}$} \\
\hline \multirow[t]{2}{*}{ Corporation dummy } & -0.025 & 0.029 & -0.121 & 0.165 & -0.184 & 0.033 & -0.039 & -0.295 \\
\hline & {$[0.507]$} & {$[0.552]$} & {$[0.002]^{* * *}$} & {$[0.231]$} & {$[0.000]^{* * *}$} & {$[0.762]$} & {$[0.305]$} & {$[0.000]^{* * *}$} \\
\hline \multirow[t]{2}{*}{ Log GDP PC } & -0.2 & -0.2 & -0.159 & -0.153 & -0.334 & -0.334 & -0.186 & -0.181 \\
\hline & {$[0.000]^{* * *}$} & {$[0.000]^{* * *}$} & {$[0.000]^{* * *}$} & {$[0.000]^{* * *}$} & {$[0.000]^{* * *}$} & {$[0.000]^{* * *}$} & {$[0.000]^{* * *}$} & {$[0.000]^{* * *}$} \\
\hline \multirow[t]{2}{*}{ Financial Development } & -0.134 & -0.08 & & & & & & \\
\hline & {$[0.000]^{* * *}$} & {$[0.063]^{*}$} & & & & & & \\
\hline Financial Development * & & -0.091 & & & & & & \\
\hline Corporation Dummy & & {$[0.071]^{*}$} & & & & & & \\
\hline \multirow[t]{2}{*}{ Law and Order } & & & -0.109 & -0.08 & & & & \\
\hline & & & {$[0.000]^{* * *}$} & {$[0.001]^{* * *}$} & & & & \\
\hline Law and Order $*$ & & & & -0.068 & & & & \\
\hline Corporation Dummy & & & & {$[0.033]^{* *}$} & & & & \\
\hline \multirow[t]{2}{*}{ Corruption } & & & & & -0.116 & -0.082 & & \\
\hline & & & & & {$[0.000]^{* * *}$} & {$[0.001] * * *$} & & \\
\hline Corruption * & & & & & & -0.067 & & \\
\hline Corporation Dummy & & & & & & {$[0.027]^{* *}$} & & \\
\hline \multirow[t]{2}{*}{ Duration of entry } & & & & & & & -0.001 & -0.003 \\
\hline & & & & & & & {$[0.049]^{* *}$} & {$[0.000]^{* * *}$} \\
\hline \multirow[t]{2}{*}{ Tax Disadvantage } & & & & & & & -0.006 & -0.01 \\
\hline & & & & & & & {$[0.001]^{* * *}$} & {$[0.000]^{* * *}$} \\
\hline Duration of Entry * & & & & & & & & 0.005 \\
\hline Corporation Dummy & & & & & & & & {$[0.000]^{* * *}$} \\
\hline Tax Disadvantage * & & & & & & & & 0.006 \\
\hline Corporation Dummy & & & & & & & & {$[0.095]^{*}$} \\
\hline Number of Observations & 3901 & 3901 & 3816 & 3816 & 3875 & 3875 & 3891 & 3891 \\
\hline Number of Countries & 50 & 50 & 52 & 52 & 52 & 52 & 48 & 48 \\
\hline
\end{tabular}

Robust $\mathrm{p}$ values in brackets

* significant at 10\%; ** significant at 5\%; *** significant at $1 \%$ 


\section{Table IV \\ Firm Incorporation and Sales Growth}

Dependent variable is estimated percent of real sales growth over last 3 year. Foreign is a dummy for foreign ownership, Exporter is a dummy for exporters, Manufacturing and Service are industry dummies, Small and Medium are size dummies, GDPPC is real GDP per capita, Financial Development equals to sum of credit to the private sector and market capitalization to GDP, Law and Order is a measure of the law and order tradition of a country, Institutions is an index equal to first principal component of Law and Order, Financial Development, Corruption, Duration of Entry, and Time in Bankruptcy. See Table A1 for more detailed definitions and sources. All models are estimated by OLS with heteroskedasticity robust standard errors.

\begin{tabular}{|c|c|c|c|c|}
\hline & $(1)$ & (2) & (3) & (4) \\
\hline Foreign ownership dummy & $\begin{array}{l}0.047 \\
{[0.005]^{* * *}}\end{array}$ & $\begin{array}{l}0.046 \\
{[0.006]^{* * *}}\end{array}$ & $\begin{array}{l}0.042 \\
{[0.017]^{* *}}\end{array}$ & $\begin{array}{l}0.041 \\
{[0.020]^{* *}}\end{array}$ \\
\hline Exporeter dummy & $\begin{array}{l}0.069 \\
{[0.000]^{* * *}}\end{array}$ & $\begin{array}{l}0.068 \\
{[0.000]^{* * *}}\end{array}$ & $\begin{array}{l}0.052 \\
{[0.001]^{* * *}}\end{array}$ & $\begin{array}{l}0.051 \\
{[0.001]^{* * *}}\end{array}$ \\
\hline Manufacturing & $\begin{array}{l}-0.041 \\
{[0.054]^{*}}\end{array}$ & $\begin{array}{l}-0.04 \\
{[0.058]^{*}}\end{array}$ & $\begin{array}{l}-0.022 \\
{[0.324]}\end{array}$ & $\begin{array}{l}-0.022 \\
{[0.323]}\end{array}$ \\
\hline Services & $\begin{array}{l}-0.004 \\
{[0.834]}\end{array}$ & $\begin{array}{l}-0.005 \\
{[0.813]}\end{array}$ & $\begin{array}{l}0.005 \\
{[0.804]}\end{array}$ & $\begin{array}{l}0.005 \\
{[0.826]}\end{array}$ \\
\hline Log of firm age & $\begin{array}{l}0.001 \\
{[0.874]}\end{array}$ & $\begin{array}{l}-0.001 \\
{[0.891]}\end{array}$ & $\begin{array}{l}-0.008 \\
{[0.275]}\end{array}$ & $\begin{array}{l}-0.01 \\
{[0.190]}\end{array}$ \\
\hline Small & $\begin{array}{l}-0.077 \\
{[0.000]^{* * *}}\end{array}$ & $\begin{array}{l}-0.079 \\
{[0.000]^{* * *}}\end{array}$ & $\begin{array}{l}-0.089 \\
{[0.000]^{* * *}}\end{array}$ & $\begin{array}{l}-0.09 \\
{[0.000]^{* * *}}\end{array}$ \\
\hline Medium & $\begin{array}{l}-0.024 \\
{[0.185]}\end{array}$ & $\begin{array}{l}-0.025 \\
{[0.174]}\end{array}$ & $\begin{array}{l}-0.018 \\
{[0.353]}\end{array}$ & $\begin{array}{l}-0.018 \\
{[0.357]}\end{array}$ \\
\hline Corporation dummy & $\begin{array}{l}-0.007 \\
{[0.626]}\end{array}$ & $\begin{array}{l}-0.122 \\
{[0.012]^{* *}}\end{array}$ & $\begin{array}{l}-0.013 \\
{[0.371]}\end{array}$ & $\begin{array}{l}-0.012 \\
{[0.391]}\end{array}$ \\
\hline Law and Order & $\begin{array}{l}0.026 \\
{[0.000]^{* * *}}\end{array}$ & $\begin{array}{l}0.013 \\
{[0.113]}\end{array}$ & & \\
\hline Law and Order* Corporation & & $\begin{array}{l}0.028 \\
{[0.010]^{* *}}\end{array}$ & 0.031 & 0.022 \\
\hline Institutions & & & {$[0.000]^{* * *}$} & $\begin{array}{l}{[0.000]^{* * *}} \\
0.016\end{array}$ \\
\hline Institutions * Corporation & & & & {$[0.040]^{* *}$} \\
\hline Observations & 2769 & 2769 & 2420 & 2420 \\
\hline R-squared & 0.035 & 0.037 & 0.046 & 0.047 \\
\hline
\end{tabular}

Robust $\mathrm{p}$ values in brackets

* significant at $10 \% ; * *$ significant at $5 \%$; ** significant at $1 \%$ 
Table A1. Variable Definitions and Sources

\begin{tabular}{|c|c|c|}
\hline \multicolumn{3}{|c|}{ Country-Level Variables } \\
\hline Variable & Definition & Original source \\
\hline GDP per capita & Real per capita GDP, average $1995-99$ & World Development Indicators \\
\hline Financial & Sum of credit by deposit money banks to the private sector to GDP and & Beck, Demirguc-Kunt and \\
\hline Development & $\begin{array}{l}\text { Market capitalization to GDP (whenever the latest is not available it is set to } \\
\text { zero), average 1995-1999. }\end{array}$ & oLevine (2000). \\
\hline Law and Order & $\begin{array}{l}\text { Measure of the law and order tradition of a country. It is an average over } \\
\text { 1995-97. It ranges from } 6 \text {, strong law and order tradition, to 1, weak law } \\
\text { and order tradition. }\end{array}$ & $\begin{array}{l}\text { International Country Risk } \\
\text { Guide (ICRG). }\end{array}$ \\
\hline Corruption & $\begin{array}{l}\text { Measure of corruption in government. It ranges from } 1 \text { to } 6 \text { and is an } \\
\text { average over 1995-97. Lower scores indicate that "high government } \\
\text { officials are likely to demand special payments" and "illegal payments are } \\
\text { generally expected throughout lower levels of government" in the form of } \\
\text { "bribes connected with import and export licenses, exchange controls, tax } \\
\text { assessment, policy protection, or loans." }\end{array}$ & $\begin{array}{l}\text { International Country Risk } \\
\text { Guide (ICRG). }\end{array}$ \\
\hline Tax disadvantage & $\begin{array}{l}\text { Measure of tax disadvantage of corporations equal to the difference of } \\
\text { maximum of corporate tax rate minus maximum personal tax rate. }\end{array}$ & $\begin{array}{l}\text { Index of Economic Freedom, } \\
\text { and Price Waterhouse (2002) } \\
\text { "Corporation Taxes : } \\
\text { Worldwide Summaries" }\end{array}$ \\
\hline Shareholder & An index of shareholder rights equal to the sum of (1) proxy by mail, (2) & La Porta et al (1998) \\
\hline Rights & $\begin{array}{l}\text { deposit of shares is not required prior to the general meeting, (3) cumulative } \\
\text { voting or proportional representation, (4) an oppressed minorities } \\
\text { mechanism is in place, (5) minimum percentage to call extraordinary } \\
\text { meeting is less or equal to } 10 \% \text { and (6) preemptive rights. }\end{array}$ & \\
\hline Creditor Rights & $\begin{array}{l}\text { An index of creditor rights equal to the sum of (1) creditor's consent } \\
\text { required for reorganization, ( } 2 \text { ) no automatic stay on assets (3) secured } \\
\text { creditors paid first and (4) the debtor does not retain the administration of } \\
\text { its property pending the resolution of the reorganization. }\end{array}$ & La Porta et al (1998) \\
\hline Legal origin & $\begin{array}{l}\text { Dummies identifying the legal origin of the company law or commercial } \\
\text { code. Dummy for socialist origin is set to one for all transitional economies } \\
\text { of Eastern Europe and CIS. }\end{array}$ & La Porta et al (1998) \\
\hline Duration of Entry & $\begin{array}{l}\text { The time it takes to obtain legal status to operate a firm with limited liability } \\
\text { involved in industrial or commercial activity, in business days. }\end{array}$ & yDjankov et al (2003) \\
\hline $\begin{array}{l}\text { Percent of } \\
\text { Bankruptcies }\end{array}$ & $\begin{array}{l}\text { Ration of the number of bankruptcies per year over the total number of } \\
\text { registered firms in a country in that year, average of 1995-1999. }\end{array}$ & Claessens and Klapper (2003) \\
\hline $\begin{array}{l}\text { Time in } \\
\text { Bankruptcy }\end{array}$ & $\begin{array}{l}\text { The average duration of insolvency procedures for a standardize bankruptcy } \\
\text { case, in number of years. The time measure includes all delay due to legal } \\
\text { derailment tactics that parties to the insolvency may use. As such, the } \\
\text { measure represents the actual time of the insolvency proceedings, not the } \\
\text { time that the law may mandate. }\end{array}$ & $\begin{array}{l}\text { World Bank (2003) "Doing } \\
\text { Business in 2004: } \\
\text { Understanding Regulation", }\end{array}$ \\
\hline $\begin{array}{l}\text { Absolute Priority } \\
\text { in Bankruptcy }\end{array}$ & $\begin{array}{l}\text { The measure documents the order in which claims are paid in the } \\
\text { insolvency process. The measure is scaled so that higher values imply } \\
\text { stricter observance of priority. A } 1 \text { on Absolute Priority Preserved means } \\
\text { that secured creditors are paid before court costs, labor claims and tax } \\
\text { claims. A } 0.67 \text { means that secured creditors get paid second, and } 0.33 \\
\text { means they get paid third. A } 0 \text { on Absolute Priority Preserved means that } \\
\text { secured creditors get paid after all court costs, labor claims, and tax claims } \\
\text { are satisfied. }\end{array}$ & $\begin{array}{l}\text { World Bank (2003) "Doing } \\
\text { Business in 2004: } \\
\text { Understanding Regulation", }\end{array}$ \\
\hline Institutions & $\begin{array}{l}\text { First principal component factor (with factor loadings) of Law and Order } \\
(0.55) \text {, Financial Development }(0.43) \text {, Corruption }(0.47) \text {, Duration of Entry } \\
(-0.44) \text { and Time in Bankruptcy }(-0.29) \text {. }\end{array}$ & Author's calculations \\
\hline
\end{tabular}




\section{Firm-Level Variables}

\begin{tabular}{|c|c|c|}
\hline $\begin{array}{l}\text { Corporation } \\
\text { Dummy }\end{array}$ & $\begin{array}{l}\text { Equals to one if the legal organization of the company is corporation and } \\
\text { zero for partnership or sole proprietorship. }\end{array}$ & $\begin{array}{l}\text { World Business Environment } \\
\text { Survey (WBES) }\end{array}$ \\
\hline $\begin{array}{l}\text { Foreign } \\
\text { ownership } \\
\text { dummy }\end{array}$ & $\begin{array}{l}\text { Dummy variable that takes on the value one if any foreign company or } \\
\text { individual has a financial stake in the ownership of the firm, zero otherwise. }\end{array}$ & WBES \\
\hline Exporter dummy & Dummy variable that takes on the value one if firm exports, zero otherwise. & WBES \\
\hline Manufacturing & $\begin{array}{l}\text { Dummy variable that takes on the value one if firm is in the manufacturing } \\
\text { industry, zero otherwise. }\end{array}$ & WBES \\
\hline Services & $\begin{array}{l}\text { Dummy variable that takes on the value one if firm is in the service } \\
\text { industry, zero otherwise. }\end{array}$ & WBES \\
\hline $\begin{array}{l}\text { Small and } \\
\text { Medium } \\
\text { dummies }\end{array}$ & $\begin{array}{l}\text { A firm is defined as small if it has between } 5 \text { and } 50 \text { employees, medium } \\
\text { size if it has between } 51 \text { and } 500 \text { employees and large if it has more than } \\
500 \text { employees. }\end{array}$ & WBES \\
\hline Firm Age & $\begin{array}{l}\text { Equals to the log of firm age in years (the difference of } 1999 \text { and the firms } \\
\text { year of the firm's operations). }\end{array}$ & WBES \\
\hline $\begin{array}{l}\text { Financing } \\
\text { Obstacle }\end{array}$ & $\begin{array}{l}\text { How problematic is financing for the operation and growth of your } \\
\text { business: no obstacle (1), a minor obstacle (2), a moderate obstacle (3) or a } \\
\text { major obstacle (4)? }\end{array}$ & WBES \\
\hline Legal Obstacle & $\begin{array}{l}\text { How problematic is functioning of the judiciary for the operation and } \\
\text { growth of your business: no obstacle (1), a minor obstacle (2), a moderate } \\
\text { obstacle (3) or a major obstacle (4)? }\end{array}$ & WBES \\
\hline Corruption & How problematic is corruption for the operation and growth of your & WBES \\
\hline Obstacle & $\begin{array}{l}\text { business: no obstacle (1), a minor obstacle (2), a moderate obstacle (3) or a } \\
\text { major obstacle (4)? }\end{array}$ & \\
\hline Taxes and & How problematic are taxes and regulations for the operation and growth of & WBES \\
\hline Regulation & your business: no obstacle (1), a minor obstacle (2), a moderate obstacle (3) & \\
\hline Obstacle & or a major obstacle (4)? & \\
\hline Equity finance & $\begin{array}{l}\text { Share (percentage) of firm's financing over the last year coming from } \\
\text { equity, sale of stocks. }\end{array}$ & WBES \\
\hline Bank finance & $\begin{array}{l}\text { Share (percentage) of firm's financing over the last year coming from local } \\
\text { and foreign commercial banks. }\end{array}$ & WBES \\
\hline Family finance & $\begin{array}{l}\text { Share (percentage) of firm's financing over the last year coming from family } \\
\text { and friends }\end{array}$ & yWBES \\
\hline $\begin{array}{l}\text { Retained } \\
\text { Earnings }\end{array}$ & $\begin{array}{l}\text { Share (percentage) of firm's financing over the last year coming from } \\
\text { retained earnings. }\end{array}$ & WBES \\
\hline
\end{tabular}


Table A2: Number of firms by country

\begin{tabular}{|c|c|}
\hline Country & Number of firms \\
\hline Albania & 84 \\
\hline Argentina & 86 \\
\hline Armenia & 86 \\
\hline Azerbaijan & 93 \\
\hline Belarus & 58 \\
\hline Bolivia & 55 \\
\hline Brazil & 156 \\
\hline Bulgaria & 64 \\
\hline Canada & 85 \\
\hline Chile & 30 \\
\hline China & 36 \\
\hline Colombia & 49 \\
\hline Costa Rica & 30 \\
\hline Croatia & 87 \\
\hline Czech Republic & 102 \\
\hline Dominican Republic & 43 \\
\hline Ecuador & 49 \\
\hline El Salvador & 6 \\
\hline Estonia & 98 \\
\hline France & 80 \\
\hline Germany & 89 \\
\hline Guatemala & 43 \\
\hline Haiti & 60 \\
\hline Honduras & 41 \\
\hline Hungary & 87 \\
\hline Indonesia & 85 \\
\hline Italy & 18 \\
\hline Kazakhstan & 87 \\
\hline Kyrgyz Republic & 70 \\
\hline Lithuania & 104 \\
\hline Malaysia & 87 \\
\hline Moldova & 72 \\
\hline Nicaragua & 49 \\
\hline Pakistan & 86 \\
\hline Panama & 23 \\
\hline Peru & 37 \\
\hline Philippines & 97 \\
\hline Poland & 166 \\
\hline Portugal & 89 \\
\hline Romania & 99 \\
\hline Russia & 427 \\
\hline Singapore & 91 \\
\hline Slovak Republic & 93 \\
\hline Slovenia & 91 \\
\hline Sweden & 87 \\
\hline Trinidad \& Tobago & 66 \\
\hline Turkey & 117 \\
\hline USA & 78 \\
\hline Ukraine & 171 \\
\hline United Kingdom & 66 \\
\hline Uruguay & 39 \\
\hline Venezuela & 14 \\
\hline All Sample & 4206 \\
\hline
\end{tabular}

